\title{
Akılcı Antibiyotik Kullanımı
}

\author{
Aslınur ÖZKAYA PARLAKAY
}

Sağlık Bilimleri Üniversitesi, Ankara Çocuk Sağlı̆ı ve Hastalıkları Hematoloji Onkoloji SUAM, Çocuk Enfeksiyon Kliniği, Ankara, Türkiye sağlık harcamalarının azalııımasında en önemli rolü oynamaktadır. Ancak son yıllarda yapılan çalışmalar, antibiyotik tedavisinin gerekli olmadığı ya da dar spektrumlu antibiyotik tedavisinin uygun olduğu birçok durumda, geniş spektrumlu antibiyotiklerin reçete edilmesinin giderek artmakta olduğunu göstermektedir (1).

Amerika Birleșik Devletleri'nde her yll ayaktan tedavi hizmeti veren polikliniklere bașvuran her beș çocuktan en az birine antibiyotik reçete edilmekte ve bu durum her yll 50 milyondan fazla antibiyotik reçetesinin yazılmasına yol açmaktadır. Ayaktan tedavi veren kurumlarda, özellikle viral kaynaklı üst solunum yolları infeksiyonları, uygun olmayan antibiyotik tedavisinin en sık yapıldığı durumlardır.

Ülkemizde ise Sağlık Bakanlığı tarafından 2003'te başlatılan Akılcı Antibiyotik Kullanım Programı ile hastanelerde kullanılan antibiyotiklerin enfeksiyon hastalıkları uzmanı tarafından denetimine bașlanmıș ve bu sayede geniș spektrumlu antibiyotik kullanımının azaltılması hedeflenmiștir. Dünya Sağlkk Örgütü’nün ayaktan hastalardaki yüksek antibiyotik oranlarının azaltılması yönündeki önerisiyle ülkemizde 2014-2017 yılları arasında yürütülen programla, 2015 yılında reçetesiz antibiyotik kullanımı yasaklanımış ve ayaktan hastalardaki antibiyotik kullanımının azaltılması yönünde kamu spotları ve bilgilendirme kampanyaları bașlatılmıştır. Bu sayede aile hekimlerinin reçetelerinin \%35'ini oluşturan antibiyotiklerin \%25' e oransal olarak düştüğü gözlenmiştir. Günlük antibiyotik kullanımı 2011'de 42.2 günlük doz/1000 hastadan, 2014'de 40.4 günlük doz/1000 hastaya, 2017'de 35.25 günlük doz/1000 hastaya azalmıştır (2).

Ülkemizde akılcı antibiyotik kullanımın sağlanması için bu çabaların artarak devam etmesi gerekmektedir. Bu nedenle ailelerin bilinçlendirilmesi, meslek içi eğitimlerin devamı, ayrıca çoklu ilaç direnci olan gram negatif bakterilerin kontrolü için programlar geliștirilmesi, hastanede yatan ve ayaktan hastalarda antibiyotik kullanımının yakın takibi ve patojen mikroorganizmların direnç oranlarının izlenmeli ve tarım ve hayvanclıkta kullanılan antibiyotiklerin denetimi yapılmalıdır.

Dergimizde yayınlanan Güngör A. ve ark.(3) çalısmasında çocuk polikliniğine başvuran hastaların anne babalarının antibiyotik kullanımı ile ilgili bilgi ve tutumları değerlendirilmiştir. Çalışmada, annelerde doktora gitmeden ilaç başlama oranı (\%42.9) babalara göre (\%31.8) daha yüksek saptanmış, eğitim süresi >8 yıl olanlarda doktora gitmeden ilaç başlama oranı eğitim süresi $\leq 8$ yıl olanlara göre istatistiksel olarak anlamlı düşük bulunmuştur. Katılımcıların \%4.5'i doktor önerisi dışında antibiyotik kullanırken, \%95.5'i evde yedek antibiyotik bulundurmadığı tespit edilmiştir. Bu konuda çok merkezli çalışmalar ve devam eden eğitim programlarıyla farkındalık düzeyinin artıııımasına intiyaç vardır.

\section{KAYNAKLAR}

1. Kocabaş E. Pediatrik çağda üst solunum yolu infeksiyonlarında akılcı antibiyotik kullanımı. ANKEM Derg 2014;28:185-191.

2. Isler B, Keske Ş, Aksoy M, Azap ÖK, Yilmaz M, Yavuz SŞ, Aygün G, Tigen E, Akalın H, Azap A, Ergönül Ö. Antibiotic overcosumption and resistance in Turkey. Clin Microbiol Infect 2019;25:651-53.

3. Güngör A, Çuhacı Çakır B, Yalçın H, Çakır HT, Karauzun A. Çocuklarda Antibiyotik Kullanımı ile Illgili Ebeveynlerin Tutum ve Davranışlarının Değerlendirilmesi. Türkiye Çocuk Hast Derg 2019:3: 202-6. 